\title{
DEVELOPING HORTICULTURAL PROTOCOLS FOR THREATENED PLANTS FROM THE UK OVERSEAS TERRITORIES
}

\author{
Marcella Corcoran ${ }^{1}$, Martin A. Hamilton ${ }^{2} \&$ Colin Clubbe $e^{3}$
}

\begin{abstract}
The UK Overseas Territories (UKOTs) Programme based at the Royal Botanic Garden, Kew (RBG, Kew) has an active training and seed collection programme with local partners in most of the UK's 16 Overseas Territories. Seeds are banked at the Millennium Seed Bank (MSB) for long-term storage, with a particular focus on endemic and threatened species, contributing to Target 8 of the Global Strategy for Plant Conservation (GSPC). Many of these threatened species have never been in cultivation so horticulture protocols are being developed for each species. Drawing on examples of threatened species from parts of the Caribbean and the Falkland Islands, this paper describes the components of horticulture protocols, from collection through to germination and growth in the first year. It outlines their role and value in the conservation of threatened species. These written protocols together with a short nursery guide are shared with local partners, thereby contributing to Target 3 of the GSPC.
\end{abstract}

\section{INTRODUCTION}

The Global Strategy for Plant Conservation (GSPC, 2002) provides the guiding framework for the activities that the UK Overseas Territories (UKOTs) Programme, based at the Royal Botanic Garden, Kew (RBG, Kew) undertake with local partners in the UKOTs (Clubbe et al., 2010). Individual Territories are quite different from each other; however the GSPC has provided a really useful framework for conservation action, and to help the UKOTs to implement the GSPC has become the Programme's overarching goal.

The UKOTs Programme has been developing horticultural protocols for threatened vascular plant species from UKOTs since 2007 (Hamilton et al., 2007), contributing directly to Target 3 of the GSPC. Through collaboration with UKOTs partners, these protocols provide the basis for producing plants under controlled conditions that can be used for reintroduction of the species into the wild and for the restoration of habitats. The main aim of this work is to prevent species extinctions. The last individual of a tree species endemic to St Helena, the St Helena olive, Nesiota elliptica (Roxb.) Hook.f. (Rhamnaceae), died in 2003. This resulted in the extinction of this species which now only remains as a DNA sample in the Kew DNA Bank (Kew, 2014a). It is vital to ensure

1. Marcella Corcoran is UK Overseas Territories Programme Officer and corresponding author for this paper.

Address: The Herbarium, Kew, Richmond, Surrey, TW9 3AE, UK.

Email: m.corcoran@kew.org

2. Martin A. Hamilton is UK Overseas Territories Programme Coordinator.

Address: as above

3. Colin Clubbe is Head of UK Overseas Territories Programme and Conservation Training

Address: as above 
that threatened species are secure in well-managed collections as a back-up for potential losses in the wild. For example, the endemic St Helena boxwood, Mellissia begoniifolia (Roxb.) Hook.f. (Solanaceae), was listed as extinct in the wild on the International Union for Conservation of Nature (IUCN) Red List (Walter \& Gillett, 1998), but because it was growing at Kew intensive hand pollination could be undertaken. This resulted in the collection of 13,000 seeds in 2010, most of which have been sent back to St Helena for local use both in the government endemic nursery and for experimental reintroduction into the wild (Kew, 2014b).

\section{BACKGROUND}

Horticulture protocols are a set of guidelines which have already been trialled and tested. They are predefined written procedural methods for achieving results. In recent years they have been developed to meet conservation needs, and examples include for the cultivation of rare plants in Hawaii (NTBG, 2014) and to provide species-specific horticultural knowledge for cultivating endangered plants in the UK (Crichton et al., 2012).

The protocol development work at RBG, Kew is carried out to find the best practices for germination and cultivation of UKOTs species. This is in preparation for any situation where declining species numbers may occur in the UKOTs and before we are left with the last plant alive.

After a comprehensive desk study has been completed, which pulls together all the known information for the species, the field-based activities begin. This usually includes baseline surveying and mapping with in-country partners, which gives the opportunity to provide hands-on training. The focus is on both habitat and species-level information. This enables a better picture to be developed of the vegetation and the individual species. All of the field data is captured using hand-held computers that geo-reference this data, allowing species distributions to be mapped and modelling work to be done, as demonstrated for Rondeletia buxifolia Vahl (Rubiaceae) (Clubbe et al., 2009; Jones, 2008).

Once the necessary baseline information has been obtained, species of the highest conservation priority are targeted. These may be single island endemic species such as Rondeletia buxifolia or restricted range species which occur on only a few islands such as Charianthus purpureus D. Don (Melastomataceae), both from the Caribbean island of Montserrat. The target species may be threatened with extinction globally or extirpation locally, as is the case with the national tree of the Turks and Caicos Islands, Pinus caribaea var. bahamensis (Griseb.) W.H.Barrett \& Golfari (Pinaceae), which is threatened by an invasive scale insect (Malumphy et al., 2012). Some species may be at risk due to exploitation such as the Christmas palm, Pseudophoenix sargentii H.Wendl. ex Sarg. (Arecaceae), which has been over-collected for landscaping in Florida and the Bahamas archipelago. Finally, species may fall into any of the above categories as well as being of horticultural merit such as the St Helena endemic Trochetiopsis ebenus Cronk (Malvaceae).

In situ conservation is supported by a range of ex situ conservation activities and the UKOTs team have embarked on a comprehensive seed collection and conservation 
programme in the Territories which is a natural extension to the Millennium Seed Bank's (MSB) successful banking of most of the UK's mainland native flora. The field activities are focused on capacity building and securing high-quality collections of seeds with associated herbarium vouchers and precise data about locality, population size and habitat.

In the Territories, support is given to key developments in horticultural infrastructure. This includes the establishment of native species nurseries. These nurseries are encouraging the use of native species in landscaping as a response to the current usage of non-native and, in some cases, invasive species. For example, the Falklands Islands' native plant nursery, a joint venture between Falklands Conservation and Stanley Growers, is producing native plants for the local market. There are many horticultural introductions including Berberis microphylla G.Forst. (Berberidaceae) that have escaped cultivation, become seriously invasive and are now causing major problems at both a species and habitat level. These nurseries are also establishing ex situ collections to be used for reintroduction and restoration such as the native plant nursery on Ascension Island. The Ascension nurseries are growing endemic species for restoration work following invasive species clearance. Endemic fern species, such as Pteris adscensionis Sw. (Pteridaceae), Anogramma ascensionis (Hook.) Diels (Pteridaceae) and Ptisana purpurascens (de Vriese) Murdock (Marattiaceae), which were once abundant on Green Mountain are now being grown in large numbers for reintroduction.

\section{MATERIAL AND METHODS}

\section{Design and horticulturists}

The process used in developing the protocols involves a team of horticultural staff in the nurseries at RBG, Kew. UKOTs Programme and nursery staff meet to discuss the protocol design. This is an opportunity to identify members of staff with specific expertise in the species or a closely related species as most of these species have never been in cultivation before. Following protocol design, a germination trial is undertaken. The number of replicates included is sometimes limited by seed availability. When possible there are four pots of seed used as control and eight pots of replicates used in the trial. Finally, staff working in the area are identified to take responsibility for recording germination events and undertaking observations throughout the protocol development period. This could take up to six months from the time of sowing although the time needed will generally range from four to twelve weeks.

Next, a one-year cultivation trial is carried out with monitoring of individual plants to record plant health and issues related to cultivation. Replicates are usually divided into different media and climatic conditions. Finally a data recording session is undertaken to assess overall condition and growth. Once the protocol is complete and data are collected, results are analysed and the final document is produced for circulation to our UKOTs partners. 


\section{Climatic conditions}

At Kew there are many different nursery facilities providing the ability to grow plants in a range of different growing conditions. Some facilities are small, self-contained units that enable precise control of climatic conditions. Other facilities, such as the Tropical Nursery, house many different collections across 21 different climatic zones. The staff who work in these facilities have a vast range of knowledge and experience. These facilities and personnel provide the opportunity to develop 'back to basics' horticultural protocols for a range of species. The temperature, humidity and light levels are kept as close to the native environment of species cultivated as possible.

\section{Seed material}

Seeds of UKOTs species used for protocols come from one of two sources, either small field collections sent directly to Kew, or those removed from larger collections sent to Kew's MSB. The protocols focus on documenting how to turn these seeds back into plants; producing the best techniques for germination and cultivation of the species using low-tech methods. Seed treatments are completed where necessary. For example, methods such as scarification, priming or breaking dormancy may be used.

\section{Growing media}

The protocol design includes choosing the growing media that will be used - normally two different types, one that is as close as possible in structure to the natural soil and the other a standard coir/bark compost.

\section{CASE STUDIES}

Examples of the key components are given below; these are drawn from several of the completed protocols to illustrate the process used in developing horticultural protocols. The examples will be drawn from protocols completed for:

Acacia anegadensis Britton (Leguminosae) - a tree endemic to the British Virgin Islands, restricted to two islands (Hamilton et al., 2007). The species is listed as Critically Endangered on the IUCN Red List (IUCN, 2014).

Rondeletia buxifolia Vahl (Rubiaceae) - a shrub endemic to the island of Montserrat in the Lesser Antilles (Clubbe et al., 2009). It has been assessed as Critically Endangered on the IUCN Red List (IUCN, 2014).

Varronia rupicola (Urb.) Britton (Boraginaceae) - a Puerto Rican Bank (British Virgin Islands (BVI), US Virgin Islands and Puerto Rico) endemic that is restricted to three islands in the British Virgin Islands (Anegada) and Puerto Rico (south-west Puerto Rico and Vieques) (Wenger et al., 2010). It has been assessed as Critically Endangered on the IUCN Red List (IUCN, 2014). 
Symphyotrichum vahlii (Gaudich.) G.L.Nesom (Asteraceae) - a native of the Falkland Islands (Corcoran et al., 2012) and currently listed on IUCN as Least Concern (IUCN, 2014).

\section{Protocol design}

The protocol developed for Acacia anegadensis was the pilot and established the overall protocol practices and procedures as well as the cross-departmental relationships within RBG, Kew (Hamilton et al., 2007). The Protocol Design (Table 1 in Appendix 1) for A. anegadensis was discussed and documented using an electronic spreadsheet format. Each replicate of the trial can be followed on this spreadsheet and used as a guideline for the protocol work on the species. The spreadsheet includes the detail of each replicate for media, climate, seed treatments and numbers of seed sown, germination results and cultivation results.

\section{Germination method}

Rondeletia buxifolia is threatened by an active volcano, invasive species of plants and animals, and development of local infrastructure (Corcoran et al., 2009). Seeds collected for Kew's MSB from the wild population of $R$. buxifolia were transferred to the UKOTs Programme. Two different seed propagation methods and two germination media were trialled to produce a germination protocol. On the day of sowing, the seeds are first divided into replicate groups before any required treatments such as scarification or chipping are completed. Sowing media are prepared and put into appropriate labelled containers. The corresponding medium type and seed treatment is recorded in the protocol design spreadsheet (Table 2 in Appendix 1). Once seed sowing has been completed the pots are placed in two different propagation units. As germination occurs, plastic cocktail sticks are used to mark each emerging seedling. These markers help ensure that germination events are accurate if seedlings die. The germination event is recorded on a dedicated germination record sheet (Table 3 in Appendix 1).

\section{Pre-sow treatments}

$R$. buxifolia seeds were divided into twelve batches each consisting of six seeds. Six seeds were sown per pot. Each pot represented a replicate or control. A method for sowing seeds was developed, as the seeds were difficult to handle due to their small size. Masks were worn to help prevent accidental loss of seeds due to the breath of the horticulturists (Fig. 1a). The moistened tip of a pencil was used to pick up seeds individually, for more accurate sorting (Fig. 1b). 


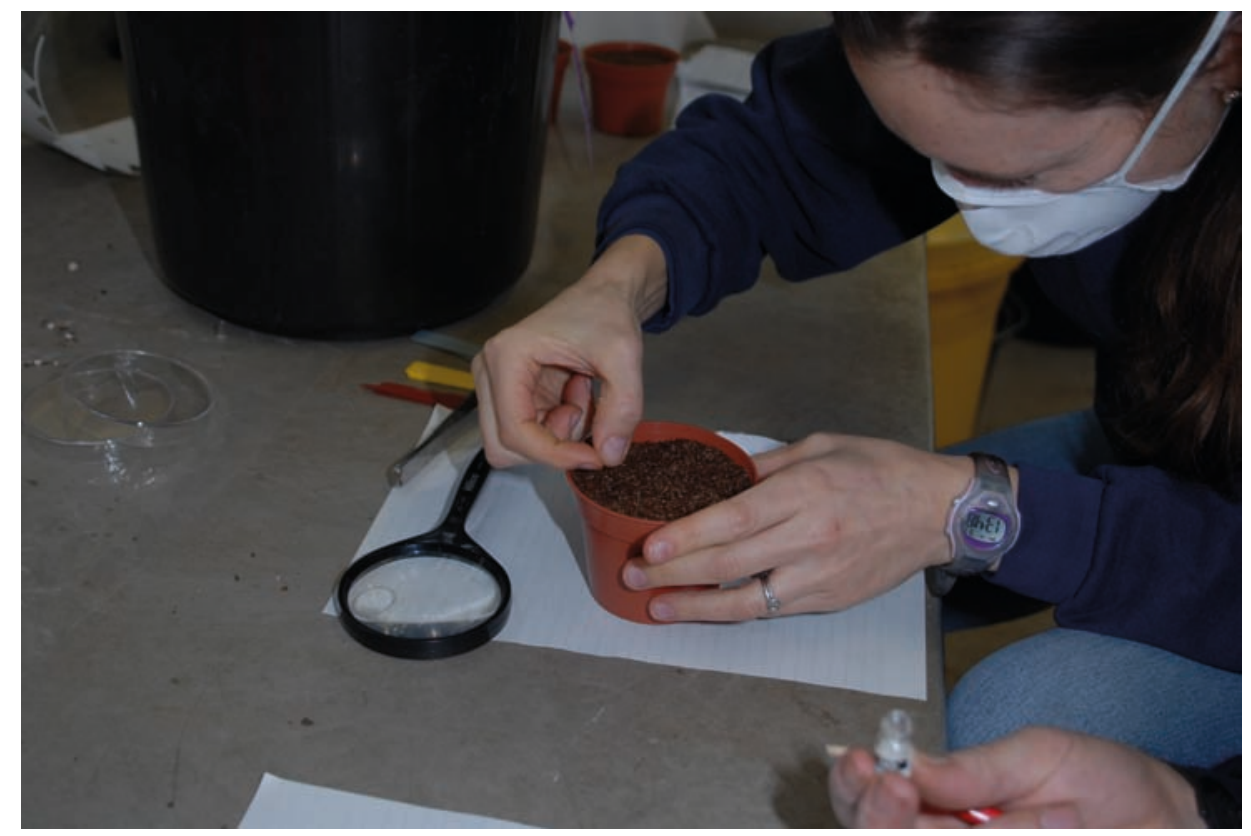

Fig. 1a Sowing very small seeds with a dust mask barrier for breath. Photo: Martin A. Hamilton.

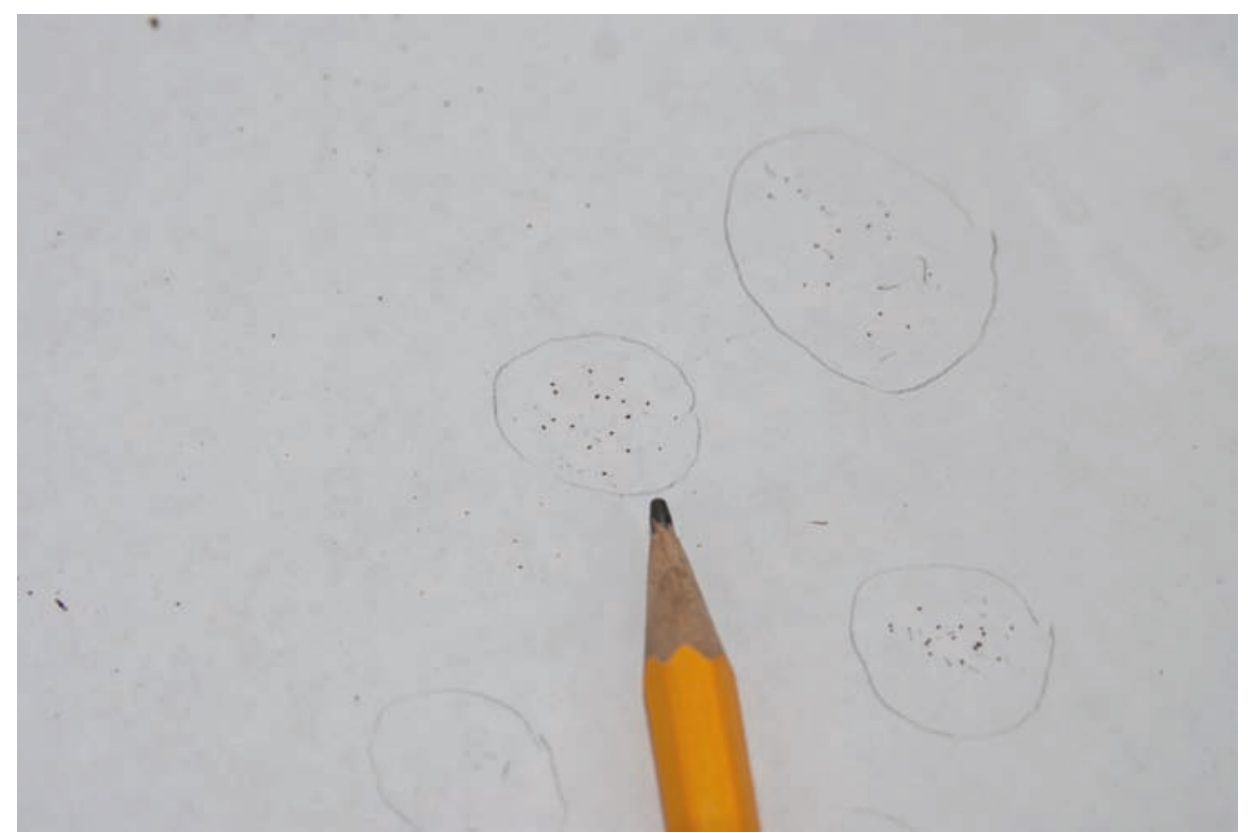

Fig. 1b Moving and grouping counted seed for each replicate. Photo: Marcella Corcoran. 


\section{Germination media}

There are a wide range of media available at Kew for seed sowing (Table 4 in Appendix 1). For this trial, Medium 1 is the standard Kew seed-sowing medium; however, a quality coir-based medium is not readily accessible in the Caribbean. Medium 2 is a non-standard Kew mix that was designed to match the natural soil structure of this species' home range. Coir can be substituted with homemade compost.

Seed Medium 1: 3:1 coir:sand

Seed Medium 2: 2:1:1 loam:sand

\section{Seed sowing}

The $R$. buxifolia seeds were direct-sown no less than $15 \mathrm{~mm}$ apart onto the growing medium, lightly covered with the same mix to the depth of the seed or a little more, lightly pressed flat and watered from the base (immersion method). Each replicate was covered with a Petri dish; the control group was left uncovered (Table 2). Seeds were sown into exactly the same size pots. The pots were then placed into propagation tanks, in two different climatic conditions. Both areas provide bottom heat within the propagation tanks. Climate $1\left(\min .20^{\circ} \mathrm{C}\right.$, max. $30^{\circ} \mathrm{C}$, RH $85 \%$ ) is maintained warmer and more humid than climate $2\left(\min .11^{\circ} \mathrm{C}\right.$, $\max .30^{\circ} \mathrm{C}$, RH $\left.50-60 \%\right)$.

\section{Monitoring}

Seeds were monitored daily to ensure that the compost was adequately moist. On Monday, Wednesday and Friday of each week checks were made to note newly germinated seeds. Germination was recorded when the seedling cotyledons were visible (Fig. 2). A cocktail stick was used to mark individual seedlings as they emerged from the medium to prevent seedlings being recounted. Germination results were recorded using a UKOTs standard germination record sheet (Table 3). General observations were made once a week which looked at pest and disease, change in climate and general health of seedlings.

\section{Watering}

The newly potted seeds were initially watered using the immersion method. Pots were checked daily and watered accordingly using a watering lance fitted with a fine or misting rose. Compost was kept moist at all times. Care was taken not to overwater the young plants as overwatering can encourage fungal and bacterial diseases which infect seeds and seedlings, causing 'damping off'. Once germination has ceased for at least two weeks the trial is completed and the results recorded in the protocol design spreadsheet.

Before starting the cultivation trial, the seedlings were hardened off for a period 


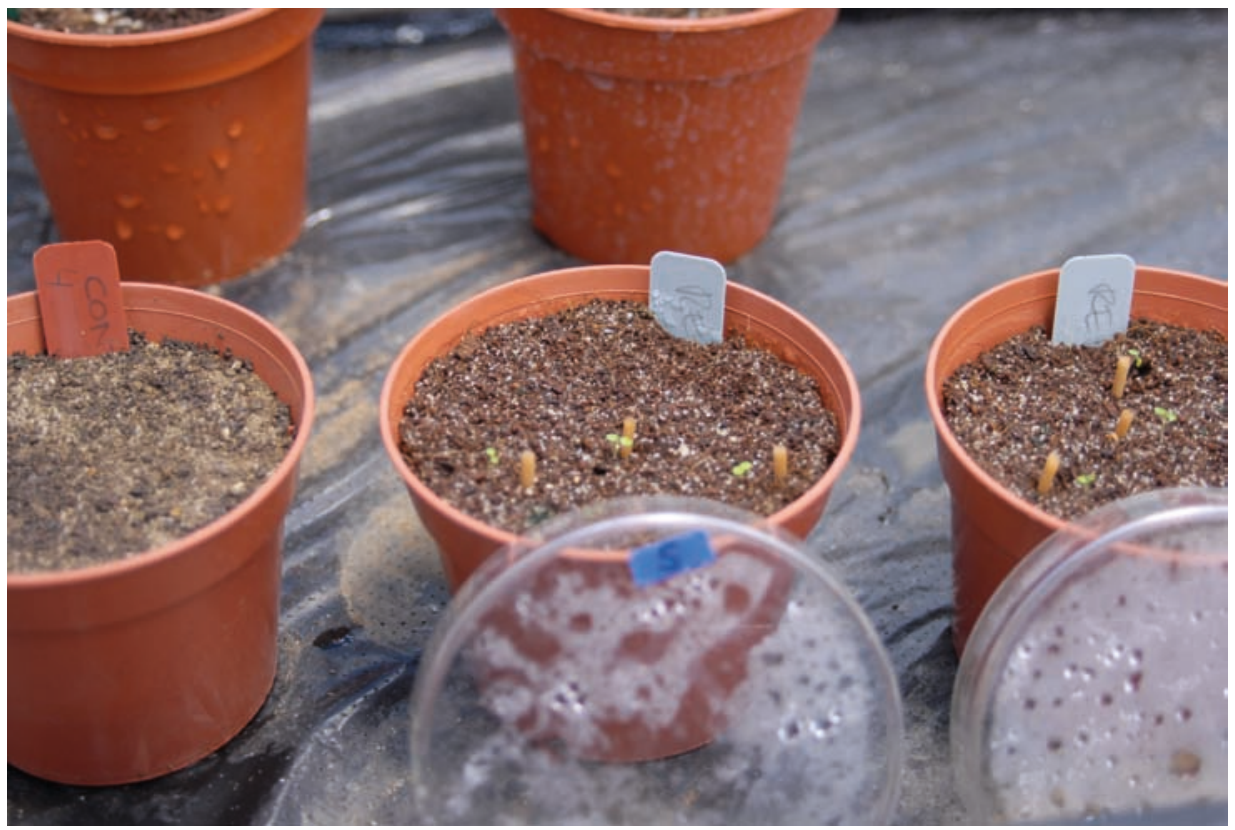

Fig. 2 Recording germination events with cocktail sticks. Photo: Marcella Corcoran.

of two weeks on an unheated bench. This hardening-off period allows the seedlings to become more robust and to cope better with the transfer to an individual pot.

\section{Cultivation methods}

After germinating (nine weeks from sowing and two weeks to harden off) the seedlings of Varronia rupicola were removed from the propagation zones and pricked out into 9B 'Plantpak' (Desch Plantpak, 2014) pots. Care was taken not to damage the immature and vulnerable root systems when the seedlings were transferred into two types of growing medium selected for the cultivation trial (Fig. 3). Following immersion watering, the seedlings were returned to the propagation zones for two more weeks, again on unheated benches, to settle into the pots before being relocated.

Seedlings in cultivation are trialled to assess environmental and horticultural preferences for the species as part of an ex situ collection. Half of the seedlings from each of the two different types of medium were placed into two glasshouse zones with different climatic conditions.

\section{Cultivation media}

The choice of growing medium was heavily influenced by the natural growing conditions of $V$. rupicola in its native habitat. The species has a preference for very free-draining 


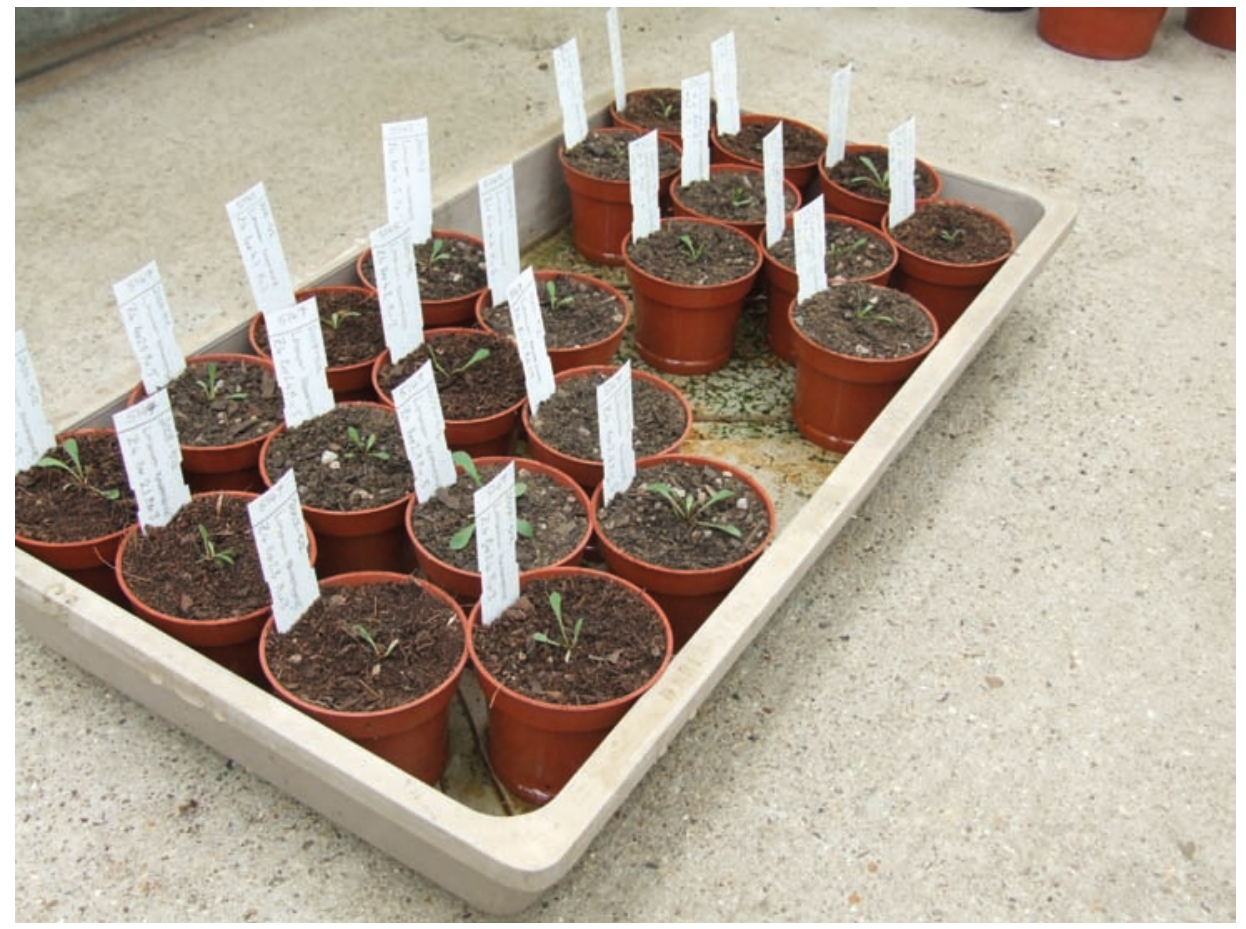

Fig. 3 Pricking out into two media and watering from the pot base. Photo: Marcella Corcoran.

substrate that is low in nutrients (particularly nitrogen and phosphorus) with very little organic matter. Therefore, the aim was to replicate as near as possible these characteristics in one growing medium produced in the Tropical Nursery (Table 4).

Growing Medium 1, known as Kew mix 3 (Fig. 4a), is Kew's most widely used potting mix. It is nutrient rich and has a high percentage of organic matter content. Growing Medium 2, known as BVI mix (Fig. 4b), was chosen to replicate those conditions found in V. rupicola's natural habitat. It has free draining qualities, minimal organic content and low nutrient availability. Imidasect $5 \mathrm{GR}^{3}$, a systemic insecticide granule used to reduce pests, was incorporated into the growing media at a ratio of $28 \mathrm{gm} / 1001$ (Fargro, 2014).

\section{Environmental conditions}

Pots of sown seedlings were then divided equally between two growing areas within the Tropical Nursery at Kew for the purpose of the trial so comparisons could be drawn.

Climate 1: Temperature: min. day $21^{\circ} \mathrm{C}$, night $18^{\circ} \mathrm{C}$; relative humidity: minimum $65-72 \%$, venting at $26^{\circ} \mathrm{C}$. This area is used as a growing-on area for propagated tropical material or material due to be distributed throughout the public glasshouses situated within Kew. It also houses stock plants for Kew's Water Lily House displays and UKOTs 


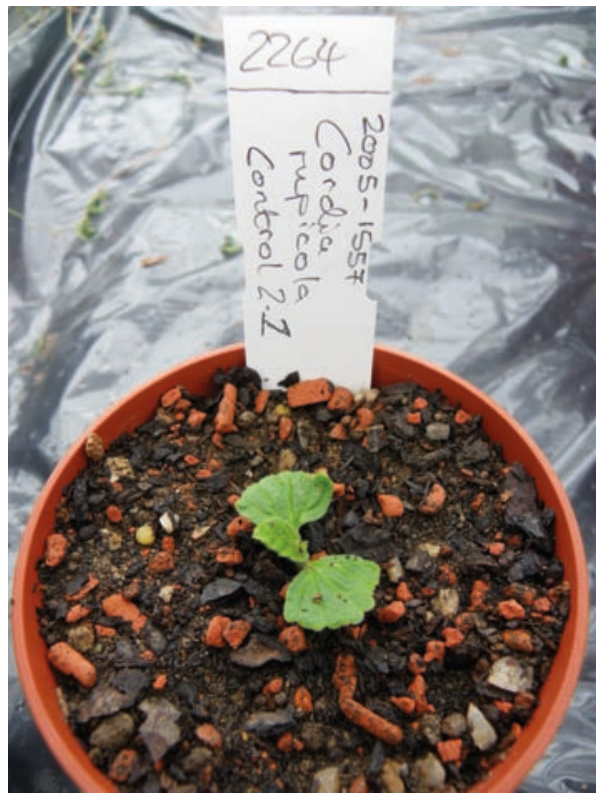

Fig. 4a Medium $1=$ Mix 3. Photo: Marcella Corcoran.

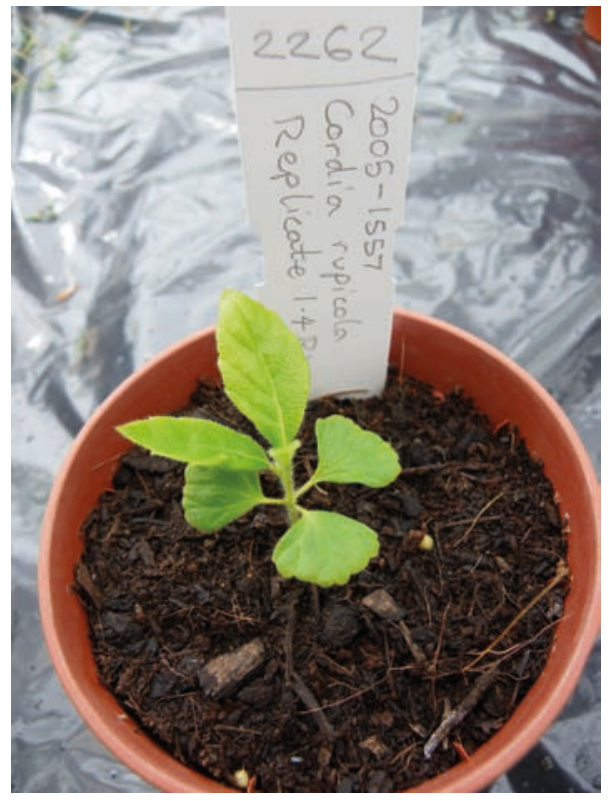

Fig. 4b Medium 2 = BVI mix. Photo: Marcella Corcoran.

conservation collections from BVI and Montserrat. Maximum temperature and humidity are subject to weather conditions, ventilation and watering. Two fixed fans are permanently running, which encourages good air flow and helps prevent disease. Lighting is used to lengthen the daylight hours in the winter to replicate a 12-hour day.

Climate 2: Temperature: min. day $10^{\circ} \mathrm{C}$, night $8^{\circ} \mathrm{C}$, ambient humidity, venting at $15^{\circ} \mathrm{C}$. This area houses conservation collections from the Canary Islands, Easter Island, Madagascar and UKOTs such as St Helena as well as South African bulbs and temperate Passiflora spp. Maximum temperature and humidity are subject to weather conditions, ventilation and watering. Two fixed fans are permanently running, which encourages good air flow and helps prevent disease.

Once the new seedlings are transferred to their cultivation trial areas, they are grown for a full year with observations being undertaken weekly initially, and then monthly after approximately four weeks. The observations allow horticulturists to record overall health and to note any pest and disease or watering issues.

After growing for one year the protocol plants are brought together for a final recording of results. The team of UKOTs Programme Volunteers are usually involved in this process to provide exposure to the volunteers to the wider activities of the UKOTs programme and provide them with training opportunities (Fig. 5). 


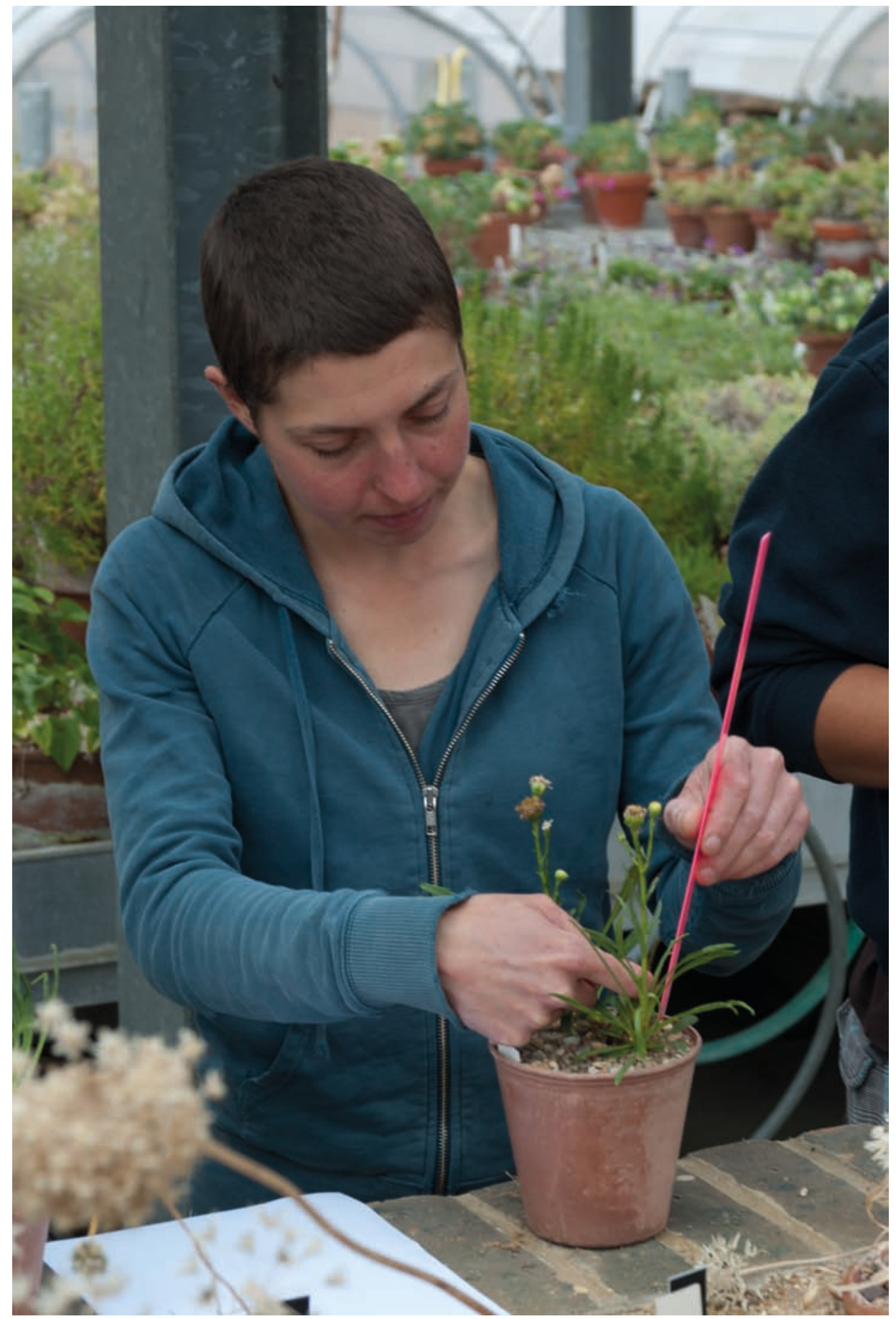

Fig. 5 UKOTs volunteers take the final recordings on plants from the cultivation trials of Symphyotrichum vahlii from the Falkland Islands. Photo: RBG, Kew. 


\section{RESULTS}

Depending on the species, the results recorded differ slightly; however, generally the main interest is in growth rates, any signs of reproduction and the overall health of each plant. These results help to identify the best methods for germination of seed and cultivation of the species using low-tech methods.

The cultivation trial results for Symphyotrichum vahlii were recorded whilst carrying out final measurements at the Alpine Nursery (Table 5 in Appendix 1). These results were later analysed and used to make graphs for the protocol document (Fig. 6) (Corcoran et al., 2012).

Most of the time there is one replicate that shows outstanding success in germination. This method is recorded on a one-page (A4 size) 'Quick Reference Sheet' (Fig. 7). This

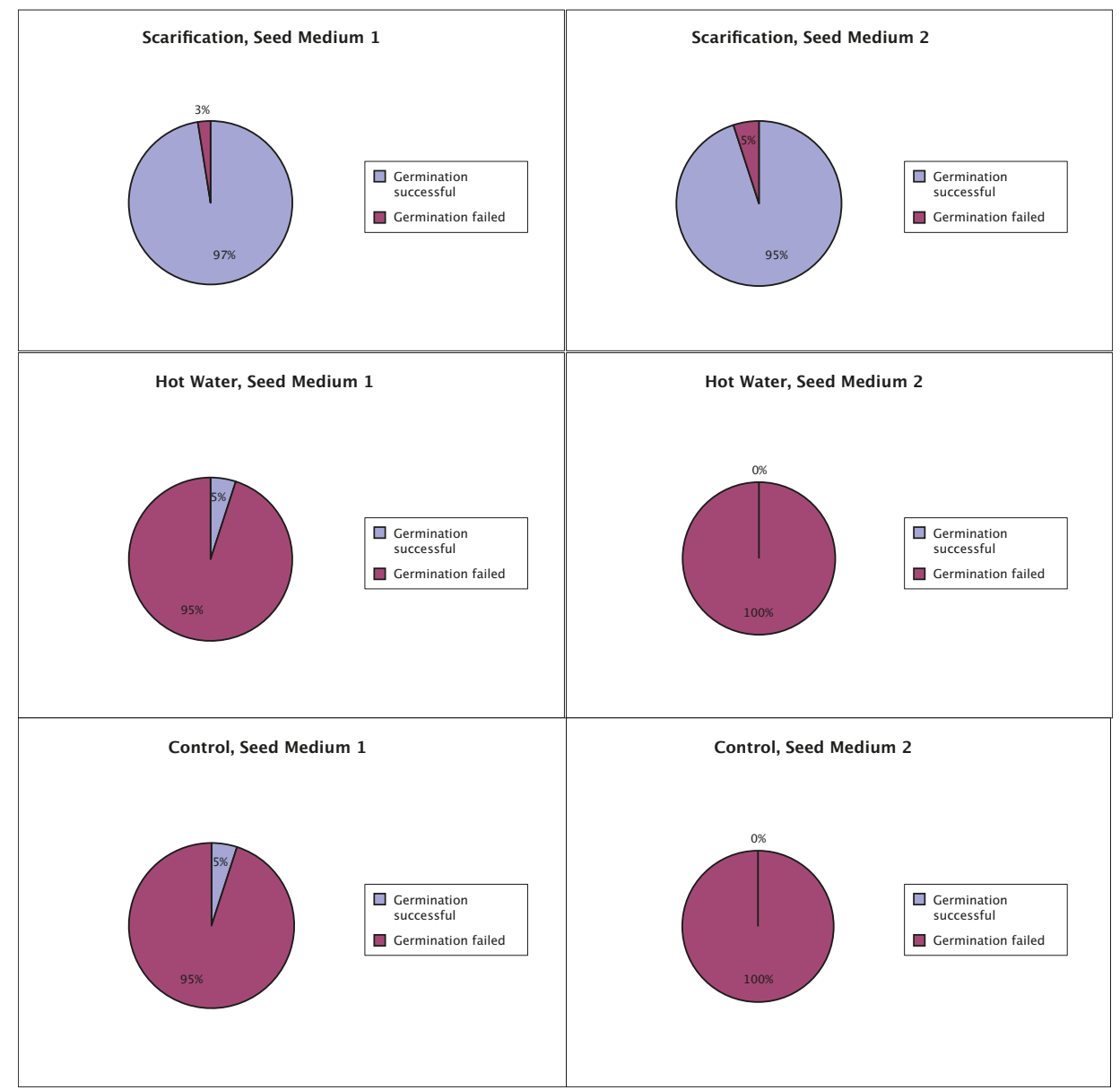

Fig. 6 Charts showing percentage of successful germination among Acacia anegadensis seeds according to pre-sow treatments and growing media. Compiled by: Marcella Corcoran. 


\section{Quick Reference Sheet 1: Acacia anegadensis Germination}

\section{- Seed Compost Ingredients}

$50 \%$ loam: sterilised, particle size $<3 \mathrm{~mm}$

$50 \%$ sharp sand, fine grit or a mixture of the two: washed

or

$70 \%$ coir: screened to $<3 \mathrm{~mm}$

$30 \%$ sharp sand: washed

- Container

Pot or similar: $70-90 \mathrm{~mm}$ in depth, $60-80 \mathrm{~mm}$ diameter, with drainage holes

\section{- Environment}

- Sterile growing conditions (pots, bench etc.)

- B right filtered light but not direct sunlight (provide shading if necessary)

- A mbient temp/humidity (in the tropics)

\section{Day 1}

a) 'N ick' the hard seed coats with a sharp blade (at the opposite end of the seed to the seed-stalk) to expose a small area of the seed's food-reserve (endosperm). **NICKING IS ESSENTIAL FOR GERMINATION**

b) Sow the Acacia seeds on the firmed compost surface, leaving no less than $15 \mathrm{~mm}$ between seeds.

c) Carefully cover the seeds with approx. $4-5 \mathrm{~mm}$, or a little more, with the seed compost.

d) Water the compost from above with a fine rose or stand the container in shallow water until moisture can be felt at the surface (1-2mins).

e) Place the newly sown seeds in a propagation case (see notes) or place on a bench out of direct sunlight.

f) The soil must be kept moist, but not waterlogged.

\section{Day 14 (approx.)}

a) Seeds germinate.

b) The soil must be kept moist, but not waterlogged.

\section{Day 42 (approx.)}

Prick out the seedlings into individual pots when the first true leaves can be seen (approx. 5- 6 weeks after sowing).

Fig. 7 Quick Reference Sheet 1: Acacia anegadensis Germination. Compiled by: Stuart Robbins. 


\section{Quick Reference Sheet 2: Acacia anegadensis First Potting}

\section{Growing Compost Ingredients}

○ $50 \%$ loam: pasteurised, screened to $<9 \mathrm{~mm}$

- $20 \%$ home-made compost: pasteurised, screened to $<9 \mathrm{~mm}$

○ $30 \%$ grit/sand: washed, $<3-5 \mathrm{~mm}$

\section{Container}

Any sterile plastic pot or similar container with drainage holes

\section{Environment}

- Sterile growing conditions (pots, bench etc.)

- B right filtered light but not direct sunlight (provide shading if necessary)

- A mbient temp/humidity (in the tropics)

1. Prick out the seedlings into individual pots when the first true leaves can be seen

2. Water well

3. The compost will provide adequate nutrients for the first 2-3 weeks

4. A fter 2-3 weeks and as the plants increase in size, a soluble feed with a low nitrogen fertiliser can be applied

5. W ater as needed, make sure compost is moist but not waterlogged and do not allow to fully dry out

6. If plants become 'leggy', prune back shoots by a third of their length; this will encourage them to bush out

7. Check the bottom of the plant pots regularly to see if roots are visible

8. If roots can be seen at the drainage holes, gently 'knock' the plant out of its pot and check the extent of the root system

9. If the roots are spreading around the 'ball' of compost it is time for them to be re-potted

Note: Subsequent re-potting should follow the above instructions.

Fig. 8 Quick Reference Sheet 2: Acacia anegadensis First Potting. Compiled by: Stuart Robbins. 
condensed, low-tech recipe is the main focus of the protocol as it provides our partners with the key elements required for growing the species. The cultivation research also culminates in a 'Quick Reference Sheet' that provides the key information for turning seedlings into young plants (Fig. 8).

The results from these protocols are combined with the most up-to-date information about the species taxonomy, distribution, threats in the wild and other conservation concerns. The reports are made available to our in-country collaborators first for comment and use before being made freely available via the UK Overseas Territories Programme pages on the Kew website (Kew, 2014c).

\section{CONCLUSIONS}

The development of horticulture protocols for plant species from UK Overseas Territories has proved to be a valuable addition to the horticulturist's toolkit for conserving threatened plants. They provide a clear set of guidelines which have been trialled and tested and are designed to meet specific conservation and horticultural needs. They are replicable and are applicable to a wide range of types of vascular plants. The published horticulture protocol brings together all the species information, conservation status and other aspects of their biology into one place to form a valuable reference source. The quick growing guides provide the key horticultural details to enable a non-specialist to grow and maintain a given species with a view to its reintroduction, display or use in educational programmes. They have been well received by in-Territory partners.

The UKOTs Programme has expanded over recent years through many successful achievements and collaborations. There are different approaches to employ for plants that are destined for field restoration and those for display or retail markets. This is taken into account in the protocol design and the final report. An excellent example of this was highlighted in the Rondeletia buxifolia protocol. There was a clear difference between plants grown in the shaded, humid, tropical climatic zone in nutrient-rich soil and those from the drier, unshaded climatic zone in nutrient-poor soil (Fig. 9). The plants growing in the climate closest to the natural environment (drier, unshaded) were drought-tolerant and flowered and produced fruit first. The other produced a lush and larger plant which would be ideal for display or for asexual propagation (cuttings) if many plants were needed in a short period of time.

At Kew, the resulting plants will be used in public display areas, for research and education. Currently there are over 150 UKOTs species being grown in the nurseries at Kew. Over 70 of these have been the result of seed collections for Kew's MSB. Many species are currently being grown for full protocols as our contribution to GSPC Target 3. Several species encountered have required specialist assistance. In these cases, the work is carried out with the staff in Kew's micro-propagation unit.

Future protocols will hopefully be an output from our comprehensive UKOTs Species and Specimens Database, using the BRAHMS software (BRAHMS, 2014), 


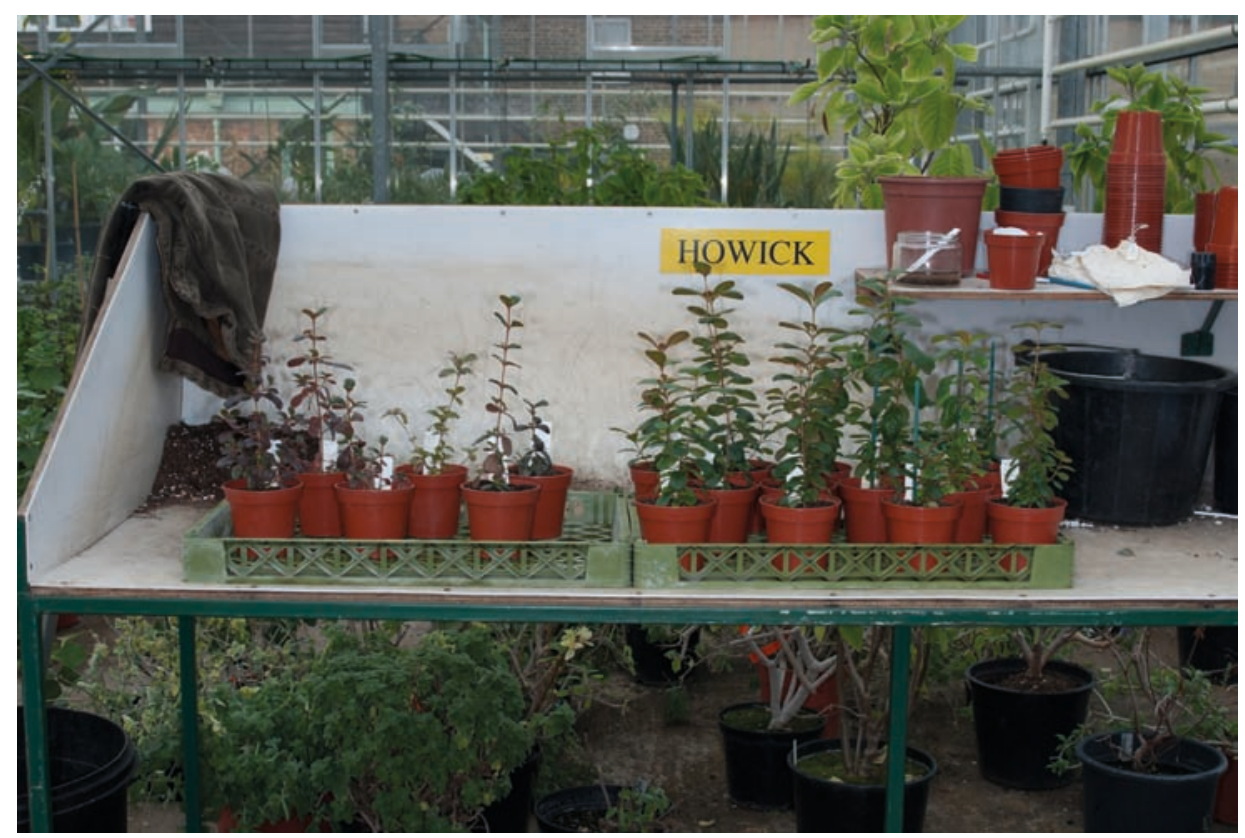

Fig. 9 Rondeletia buxifolia - a clear difference in plant growth; grown in hot, dry and sunny conditions (left) and in shady, moist and humid conditions (right). Photo: Martin A. Hamilton.

which will streamline the process of creating the final document and allow quick updates and online access.

\section{ACKNOWLEDGEMENTS}

UK - Kew staff and volunteers: Stuart Robbins, Sara Barrios, Lucy Wenger, Joy Corbett, Mark Cox, Piotr Kaminski, Bob McMeekin, Doug Brown, Rossana Porta, Miranda Kimberley, Nick Johnson, Matilda Jones, James Beattie, Nigel Rothwell, Kath Smith, Michele Sanchez, Alwyn Craven, Craig Rudman, Daisy Dent, Sheila Thomas, Janet Terry, Jo Walmisley, Kit Strange.

British Virgin Islands - National Parks Trust of the Virgin Islands: Arona De Windt, Marcus Maturine, the late Raymond Walker.

USA - Fairchild Tropical Botanic Garden: Christie Jones Leiva; University of Puerto Rico: Duane Kolterman, Gary Breckon.

Montserrat - Department of Environment: Gerard Grey, Lloyd Martin, John 'Gamby' Martin, James Boatswain, James 'Scriber' Daley, Calvin 'Blacka' Fenton, Jervaine Greenaway, Stephen Mendes; Montserrat National Trust: Philemon 'Mappie' Morrain.

Falkland Islands - Falklands Conservation: Rebecca Upson, Cynthia Williams. 


\section{FUNDING SOURCES}

Kew's Millennium Seed Bank Project (MSBP), http://www.kew.org/science-conservation/ millennium-seed-bank

The Darwin Initiative, http://darwin.defra.gov.uk/

Overseas Territories Environment Programme (OTEP), http://www.ukotcf.org/OTEP/

Environment Fund for the Overseas Territories (EFOT)

Bentham-Moxon Trust, http://www.kew.org/about/our-work

\section{REFERENCES}

BRAHMS (2014). Botanical Research and Herbarium Management Software. Available at: http://herbaria.plants.ox.ac.uk/bol (Accessed: 4 March 2014).

CLUBBE, C., HAMILTON, M. \& CORCORAN, M. (2009). Rondeletia buxifolia Rubiaceae. Plant in Peril, 32. Curtis's Botanical Magazine 26: 131-141.

CLUBBE, C., HAMILTON, M.A. \& CORCORAN, M.R. (2010). Using the Global Strategy for Plant Conservation to guide conservation implementation in the UK Overseas Territories. Kew Bulletin 65: 509-517.

CORCORAN, M.R., HAMILTON, M.A., ROBBINS, S.R. \& CLUBBE, C. (2009). Report on the status of Rondeletia buxifolia Vahl. UK Overseas Territories, RBG Kew UKOTs Horticulture Protocol Report \#2.

CORCORAN, M.R., HAMILTON, M.A. \& CLUBBE, C. (2012). Report on the status of Symphyotrichum vahlii (Gaudich.) G.L.Nesom, UK Overseas Territories, RBG Kew UKOTs Horticulture Protocol Report \#9.

CRICHTON, R.J., DALRYMPLE, S.E. \& HOLLINGSWORTH, P.M. (2012). Horticultural protocols to aid the conservation of Melampyrum sylvaticum, Orobanchaceae (small cowwheat), an endangered hemiparasitic plant. Sibbaldia 10: 57-69.

DESCH PLANTPACK (2014). Available at: http://www.desch-plantpak.com/pdf/Desch-20132014-en.pdf (Accessed: 30 March 2014).

FARGRO LIMITED (2014). Available at: www.fargro.co.uk (Accessed: 30 March 2014).

GSPC (2002). Global Strategy for Plant Conservation. Published by the Secretariat of the Convention on Biological Diversity. Available at: www.cbd.int/gspc (Accessed: 30 March 2014).

HAMILTON, M.A., ROBBINS, S.K., JOHNSON, N.P., SANCHEZ, M.D. \& CLUBBE, C. (2007). Report on the status of Acacia anegadensis Britton, UK Overseas Territories, RBG Kew UKOTs Horticulture Protocol Report \#1.

IUCN (2014). IUCN Red List of Threatened Species. Version 2013.2. Available at: www. iucnredlist.org (Accessed: 4 March 2014).

JONES, M. (2008). Distribution and conservation of Montserrat's endemic flora. Unpublished MSc thesis, Imperial College, London. Available at: http://www.iccs.org.uk/wp-content/ thesis/consci/2008/Jones.pdf (Accessed: 30 March 2014). 
MALUMPHY, C., HAMILTON, M.A., MANCO, B.N., GREEN, P.W.C., SANCHEZ, M.D., CORCORAN, M.R. \& SALAMANCA, E. (2012). Toumeyella parvicornis (Hemiptera: Coccidae), causing severe decline of Pinus caribaea var. Bahamensis in the Turks and Caicos Islands. Florida Entomologist 95(1): 113-119.

NTBG (2014). Propagation for Preservation. National Tropical Botanical Garden. Available at: http://ntbg.org/programs/livingcol.php (Accessed: 30 March 2014).

ROYAL BOTANIC GARDENS, KEW (2014a). Nesiota elliptica (St Helena olive). Available at: http://www.kew.org/science-conservation/plants-fungi/nesiota-elliptica-st-helena-olive (Accessed: 30 March 2014).

ROYAL BOTANIC GARDENS, KEW (2014b). Mellissia begoniifolia (St Helena boxwood). Available at: http://www.kew.org/science-conservation/plants-fungi/mellissia-begoniifoliast-helena-boxwood (Accessed: 30 March 2014).

ROYAL BOTANIC GARDENS, KEW (2014c). UK Overseas Territories Programme. Available at: http://www.kew.org/science-conservation/research-data/science-directory/teams/ukoverseas-territories (Accessed: 30 March 2014).

WALTER, K.S. \& GILLETT, H.J. (eds) (1998). 1997 Red List of Threatened Plants. Compiled by the World Conservation Monitoring Centre, IUCN - The World Conservation Union, Gland, Switzerland and Cambridge, UK.

WENGER, L., CORCORAN, M., HAMILTON, M.A. \& CLUBBE, C. (2010). Report on the status of Cordia rupicola Urban, UK Overseas Territories, RBG Kew UKOTs Horticulture Protocol Report \#3. 
APPENDIX 1

\begin{tabular}{|c|c|c|c|c|c|c|c|c|c|c|c|c|}
\hline \multirow[t]{2}{*}{ 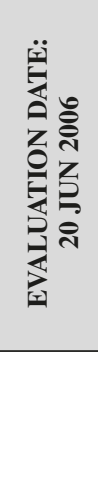 } & 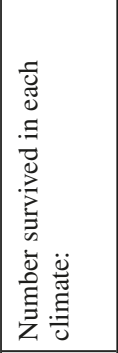 & 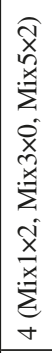 & 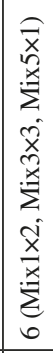 & 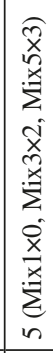 & 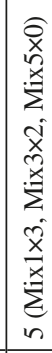 & & 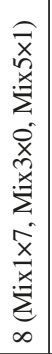 & 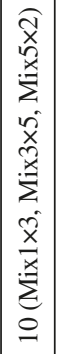 & 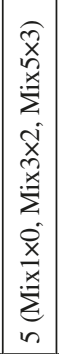 & 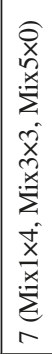 & & \multirow[t]{2}{*}{ 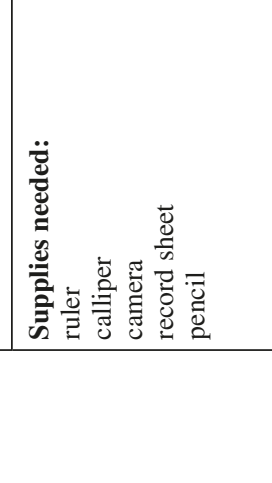 } \\
\hline & 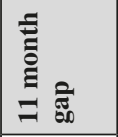 & $\ddot{\Xi}$ & 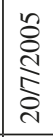 & $\ddot{\Theta}$ & 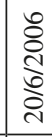 & & & & & & & \\
\hline \multirow{2}{*}{ 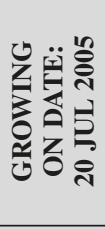 } & 壳 & $\stackrel{\infty}{-}$ & $\stackrel{\infty}{=}$ & $\stackrel{\infty}{-}$ & $\stackrel{\infty}{-}$ & & $\stackrel{\infty}{-}$ & 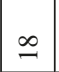 & $\stackrel{\infty}{-}$ & $\stackrel{\infty}{-1}$ & & \multirow{2}{*}{ 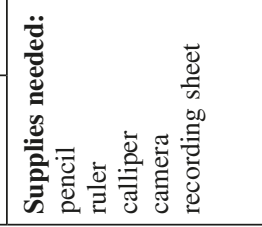 } \\
\hline & 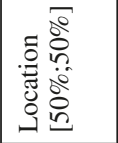 & 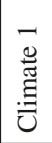 & 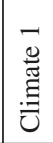 & 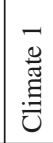 & 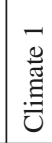 & & 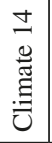 & 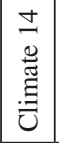 & 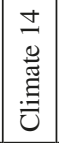 & 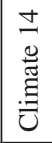 & & \\
\hline \multirow{5}{*}{ 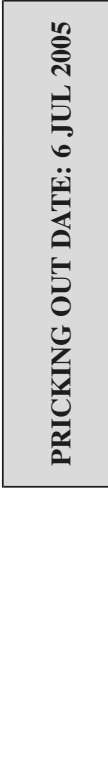 } & 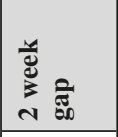 & 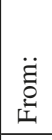 & 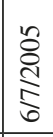 & $\ddot{\ominus}$ & 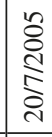 & & & & & & & \\
\hline & 䍃 & 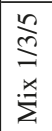 & 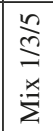 & 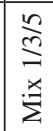 & 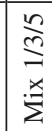 & & 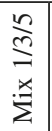 & 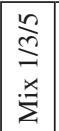 & \begin{tabular}{|l|}
$\stackrel{n}{n}$ \\
$\stackrel{n}{z}$ \\
$\stackrel{x}{z}$ \\
\end{tabular} & 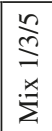 & & \multirow[b]{2}{*}{ 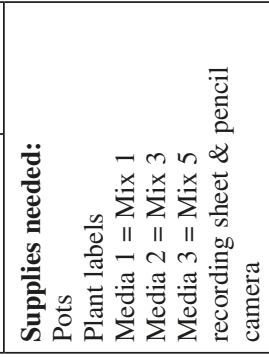 } \\
\hline & 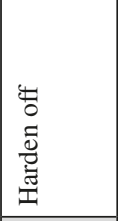 & 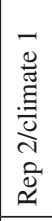 & 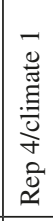 & 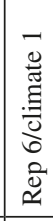 & 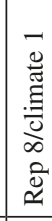 & & 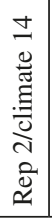 & 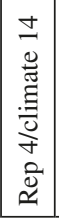 & 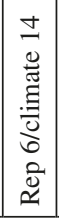 & 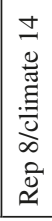 & & \\
\hline & 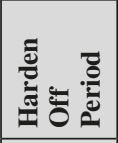 & 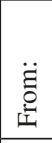 & 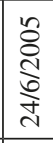 & $\ddot{\theta}$ & 苍 & 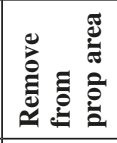 & & & & & & \\
\hline & 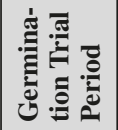 & 芫 & $\begin{array}{l}n \\
0 \\
0 \\
0 \\
0 \\
0\end{array}$ & $\ddot{\theta}$ & 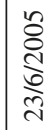 & & & & & & & \\
\hline \multirow{4}{*}{ 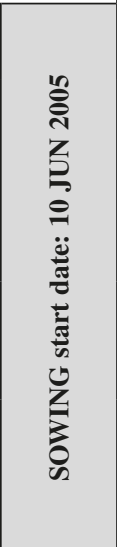 } & $\begin{array}{l}\vec{\Xi} \\
\ddot{\Delta} \\
\ddot{n}\end{array}$ & iి & స & ते & సิ & సి & ¿ิ & ते & ते & స & స & \multirow{4}{*}{ 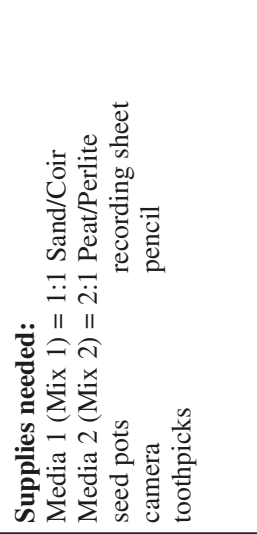 } \\
\hline & 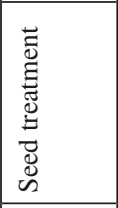 & $\overline{\bar{z}}$ & 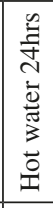 & 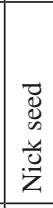 & $\bar{z}$ & 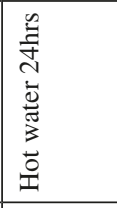 & 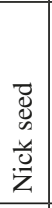 & 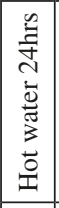 & 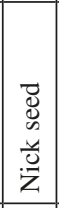 & 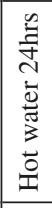 & 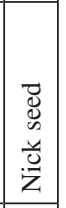 & \\
\hline & 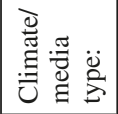 & $\bar{x}$ & $\overline{\check{\Sigma}}$ & $\bar{x}$ & $\underset{x}{*}$ & $\bar{x}$ & $\overrightarrow{\breve{z}}$ & \begin{tabular}{l|}
$N$ \\
$\stackrel{x}{\Sigma}$ \\
$\Sigma$
\end{tabular} & $\begin{array}{l}\stackrel{N}{x} \\
\stackrel{x}{\Sigma}\end{array}$ & $\mid \begin{array}{l}N \\
\stackrel{x}{\Sigma}\end{array}$ & $\mid \begin{array}{l}N \\
x \\
\dot{x}\end{array}$ & \\
\hline & & 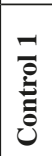 & 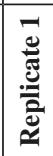 & 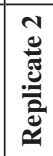 & 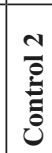 & 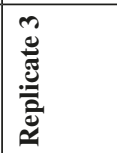 & 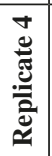 & 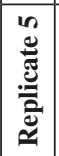 & 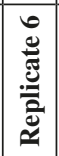 & 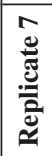 & 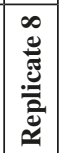 & \\
\hline
\end{tabular}




\begin{tabular}{|ll|}
\hline Control 1: & Climate 2/Media 1/No cover on sown seed \\
\hline Replicate 1: & Climate 2/Media 1/Petri dish cover on sown seed \\
\hline Replicate 2: & Climate 2/Media 1/Petri dish cover on sown seed \\
\hline Control 2: & Climate 2/Media 2/No cover on sown seed \\
\hline Replicate 3: & Climate 2/Media 2/Petri dish cover on sown seed \\
\hline Replicate 4: & Climate 2/Media 2/Petri dish cover on sown seed \\
\hline Control 3: & Climate 1/Media 1/No cover on sown seed \\
\hline Replicate 5: & Climate 1/Media 1/Petri dish cover on sown seed \\
\hline Replicate 6: & Climate 1/Media 1/Petri dish cover on sown seed \\
\hline Control 4: & Climate 1/Media 2/No cover on sown seed \\
\hline Replicate 7: & Climate 1/Media 2/Petri dish cover on sown seed \\
\hline Replicate 8: & Climate 1/Media 2/Petri dish cover on sown seed \\
\hline
\end{tabular}

Table 2 Seed Sowing Trial - Treatments for R. buxifolia. Table drawn up by: Marcella Corcoran.

\begin{tabular}{|l|l|}
\hline \multicolumn{1}{|c|}{ Growing Medium 1 (Kew Mix No. 3) } & \multicolumn{1}{|c|}{ Growing Medium 2 (Kew BVI Mix) } \\
\hline $10 \%$ loam (9mm screened and sterilised) & 1 part Kew mix No. 3 \\
$45 \%$ coir & 1 part Seramis (natural clay porous granules) \\
$45 \%$ Sylvafibre & 1 part Kew mix No. 5: \\
$+1.5 \mathrm{~g} /$ Osmocote $+15: 11: 13$ & $35 \%$ loam (9mm screened \& sterilised) \\
$+2 \mathrm{~g} \mathrm{Mo}+$ trace elements & $15 \%$ grit (sharp washed quartz $0.5-1 \mathrm{~mm})$ \\
$+0.5 \mathrm{~g} /$ Kieserite & $15 \%$ sand (kiln dried) \\
& (No fertiliser added) \\
\hline
\end{tabular}

Table 4 Growing medium mixes (all amounts in $\%$ per $\mathrm{m}^{3}$ ). Table drawn up by: Martin Hamilton. 


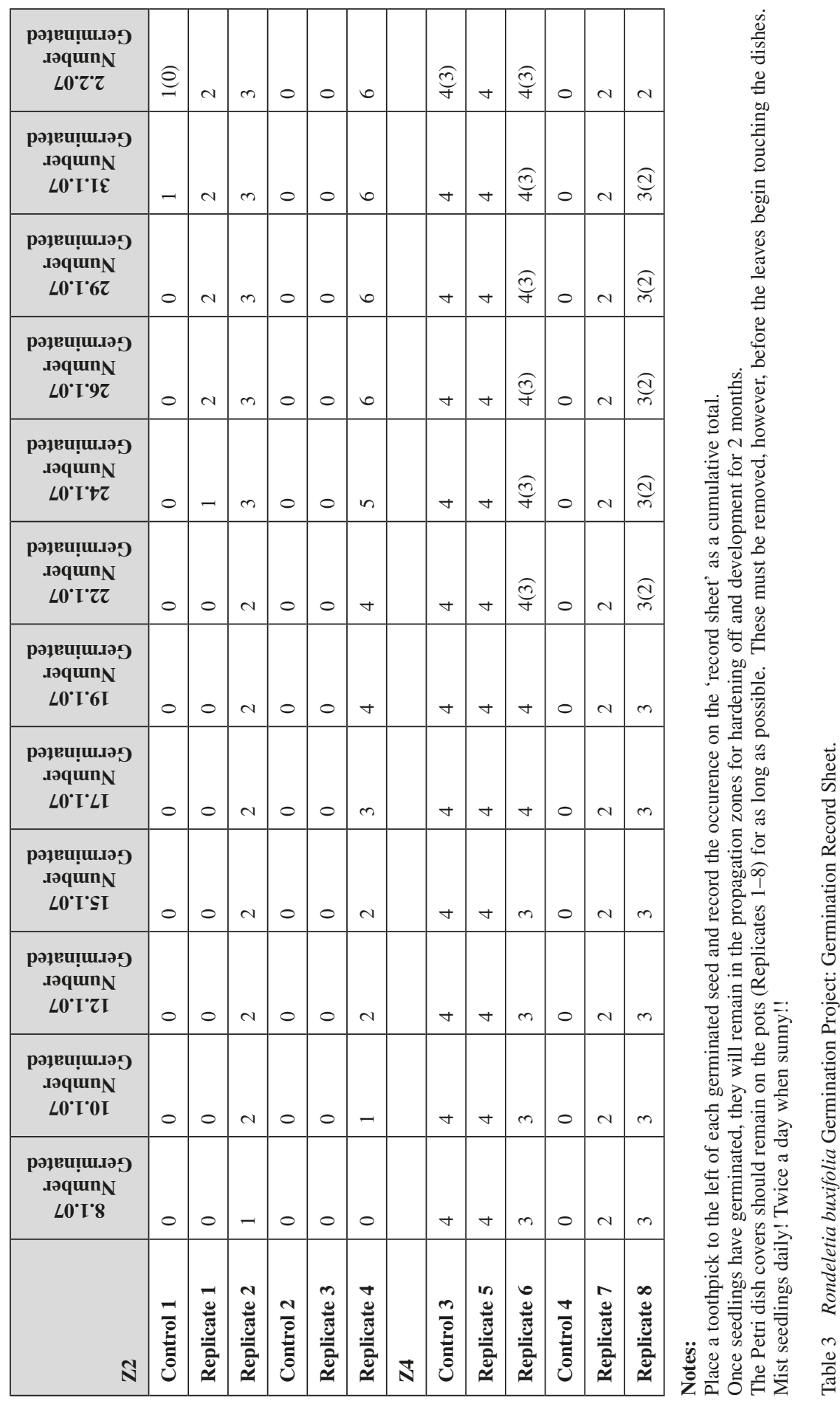




\begin{tabular}{|c|c|c|c|c|c|c|c|}
\hline \multicolumn{8}{|c|}{ Asteraceae: Symphyotrichum vahlii: Cultivation Project Results: 13 July 2011} \\
\hline $\begin{array}{c}\text { Plant } \\
\text { no. }\end{array}$ & $\begin{array}{c}\text { Plant } \\
\text { height } \\
(\mathrm{mm})\end{array}$ & $\begin{array}{l}\text { Plant } \\
\text { width } \\
(\mathrm{max}) \\
(\mathrm{mm})\end{array}$ & $\begin{array}{c}\text { Stem } \\
\text { no. }\end{array}$ & $\begin{array}{c}\text { Flower } \\
\text { stem } \\
\text { no. }\end{array}$ & $\begin{array}{c}\text { Flower } \\
\text { no. }\end{array}$ & $\begin{array}{c}\text { Leaf } \\
\text { thickness } \\
(\mathbf{m m})\end{array}$ & General notes \\
\hline 1 & 70 & 160 & 5 & 0 & 0 & 0.54 & \\
\hline 2 & 108 & 235 & 8 & 0 & 0 & 0.44 & \\
\hline 3 & 102 & 220 & 4 & 0 & 0 & 0.46 & \\
\hline 4 & 108 & 214 & 6 & 7 & 7 & 0.36 & Tortrix moth damage \\
\hline 5 & 96 & 225 & 4 & 0 & 0 & 0.53 & Leaf miner damage \\
\hline 6 & 125 & 300 & 9 & 0 & 0 & 0.33 & \\
\hline 7 & 80 & 158 & 4 & 9 & 8 & 0.52 & \\
\hline 8 & 74 & 279 & 4 & 7 & 8 & 0.42 & \\
\hline 9 & 125 & 193 & 8 & 0 & 0 & 0.53 & Tortrix moth damage \\
\hline 10 & 105 & 254 & 10 & 0 & 0 & 0.57 & Tortrix moth damage \\
\hline 11 & 55 & 145 & 5 & 0 & 0 & 0.32 & Tortrix moth damage \\
\hline 12 & 159 & 310 & 7 & 0 & 0 & 0.65 & Tortrix moth damage \\
\hline 13 & 150 & 367 & 9 & 0 & 0 & 0.41 & Scale insect and tortrix moth \\
\hline 14 & 115 & 294 & 11 & 0 & 0 & 0.38 & Scale insect and tortrix moth \\
\hline 15 & 110 & 234 & 12 & 10 & 10 & 0.46 & Tortrix moth damage \\
\hline 16 & 155 & 330 & 6 & 0 & 0 & 0.55 & Tortrix moth damage \\
\hline 17 & 128 & 290 & 8 & 3 & 3 & 0.43 & \\
\hline 18 & 47 & 136 & 5 & 2 & 2 & 0.54 & Has been deadheaded \\
\hline 19 & 45 & 118 & 7 & 13 & 11 & 0.4 & Has been deadheaded \\
\hline 20 & 55 & 143 & 6 & 1 & 1 & 0.42 & \\
\hline 21 & 55 & 114 & 3 & 0 & 0 & 0.42 & Tortrix moth damage \\
\hline 22 & 60 & 134 & 3 & 0 & 0 & 0.38 & \\
\hline 23 & 43 & 110 & 3 & 0 & 0 & 0.4 & Aphids and tortrix moth \\
\hline 24 & 94 & 78 & 1 & 0 & 0 & 0.45 & Tortrix moth damage \\
\hline 25 & 109 & 84 & 2 & 0 & 0 & 0.35 & \\
\hline 26 & 60 & 72 & 4 & 0 & 0 & 0.26 & \\
\hline 27 & 45 & 37 & 1 & 0 & 0 & 0.28 & \\
\hline 28 & 45 & 40 & 2 & 0 & 0 & 0.36 & Aphids \\
\hline 29 & 64 & 52 & 1 & 0 & 0 & 0.34 & \\
\hline
\end{tabular}

Plant height measured from base of stem (soil level) to growing tip.

Plant width at the widest part of growth.

Stem number from base of plant.

Number of stems with flowers, from base of plant.

Flower numbers include deadheads and buds.

Leaf thickness is taken next to midrib on largest leaf using calliper.

Table 5 Symphyotrichum vahlii: Cultivation project results. Table drawn up by: Marcella Corcoran. 